\title{
Study of the Possibility of Reusing Rain and Purified Water in the City of Fez, Morocco
}

\author{
Amine Couscous, Abdennasser Baali, Touria El Kamel \\ Laboratory of Geosystem, Environment and Sustainable Development, Faculty of Sciences Dhar EL Mahraz, Sidi Mohamed Ben \\ Abdallah University, Fez, Morocco \\ Email:amine.gme2@gmail.com
}

How to cite this paper: Couscous, A., Baali, A. and El Kamel, T. (2020) Study of the Possibility of Reusing Rain and Purified Water in the City of Fez, Morocco. Journal of Water Resource and Protection, 12, 120-134.

https://doi.org/10.4236/jwarp.2020.122008

Received: December 17, 2019

Accepted: January 28, 2020

Published: January 31, 2020

Copyright $\odot 2020$ by author(s) and Scientific Research Publishing Inc. This work is licensed under the Creative Commons Attribution International License (CC BY 4.0).

http://creativecommons.org/licenses/by/4.0/

\begin{abstract}
The current work seeks firstly the integration of a rainwater reuse system that will be of use in the watering of the green spaces, and secondly the reuse of purified water in the irrigation of agriculture spaces, which are in the nearby of wastewater treatment plant. The results show that $41 \%$ of the green spaces in the city of $\mathrm{Fez}$ require a renovation and installation of adequate watering systems taking into account the specificity of the city which is crossed by several rivers badly exploited for watering. The purified wastewater is of much better quality than the Moroccan reuse standards and is discharged with a flow that is large enough for the irrigation water requirements of the fields close to wastewater treatment plant.
\end{abstract}

\section{Keywords}

Reuse, Rainwater, Purified Wastewater, Irrigation, Periurban Agriculture, Green Spaces

\section{Introduction}

Throughout the world, countries look for different approaches to take advantage of wastewater reuse in irrigation [1]. In addition, the wastewater is highly significant for environmental protection of land, air and aquatic ecosystems. A further reason is related to the increasing scarcity of natural resources which are becoming limited, and thus require good, wise and efficient management to protect the environment and the public health [2]. The reuse of purified wastewater in the irrigation of agricultural fields is becoming more and more an extremely important technique; it is perfectly adapted to cities equipped with high performance purification plants as the case of the city of Fez.

The storage and management of rainwater appears relatively old and widespread as early as the $11^{\text {th }}$ and $12^{\text {th }}$ centuries [3] particularly with the Almohades, 

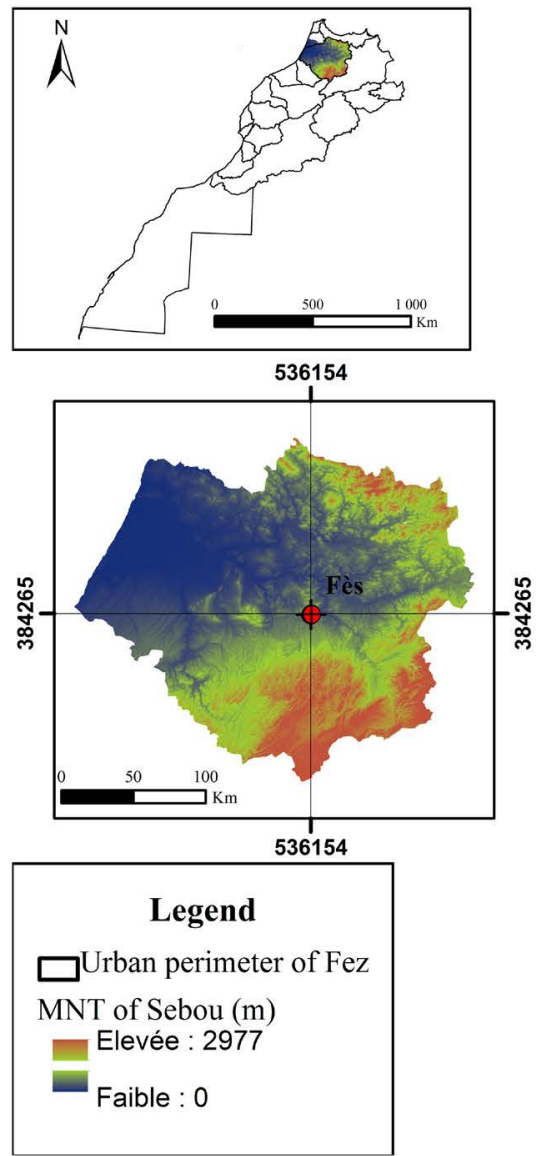

who realized several systems including cisterns as part of major hydraulic works. There is also a historical case of great interest: that of Sidi Bou Othmane (Morocco) where archaeological excavations uncovered in 1947 a hydraulic complex comprising two dams, conduits and a series of 9 cisterns arranged parallel to each other. The Sidi Bou Othmane cisterns have a total capacity of $2130 \mathrm{~m}^{3}$ [3]. The key feature of this research is that it brings together the reuse of treated wastewater along with collection of rainwater to irrigate agricultural areas and to watering green spaces respectively.

\section{Presentation of the Study Area}

\subsection{Geographical Situation}

The city of Fez is located at an altitude of $387 \mathrm{~m}$, at the point of convergence of four major natural regions, and at the intersection of three major parts of Morocco: The Middle Atlas to the south and east, the Fez-Meknes plains to the west and the Rif to the north. Its site is located at the foot of the Tghat Mountain (837 $\mathrm{m}$ ) and that of Zalagh (900 m), where the course of Oued Fès (Figure 1), after having crossed the marshy plain of Saïss, accelerates to join Oued Sebou [4]. The city of Fez is among the largest cities in Morocco and has a decisive role in the country's development. Its region is known for its economic, tourist and agricultural activity

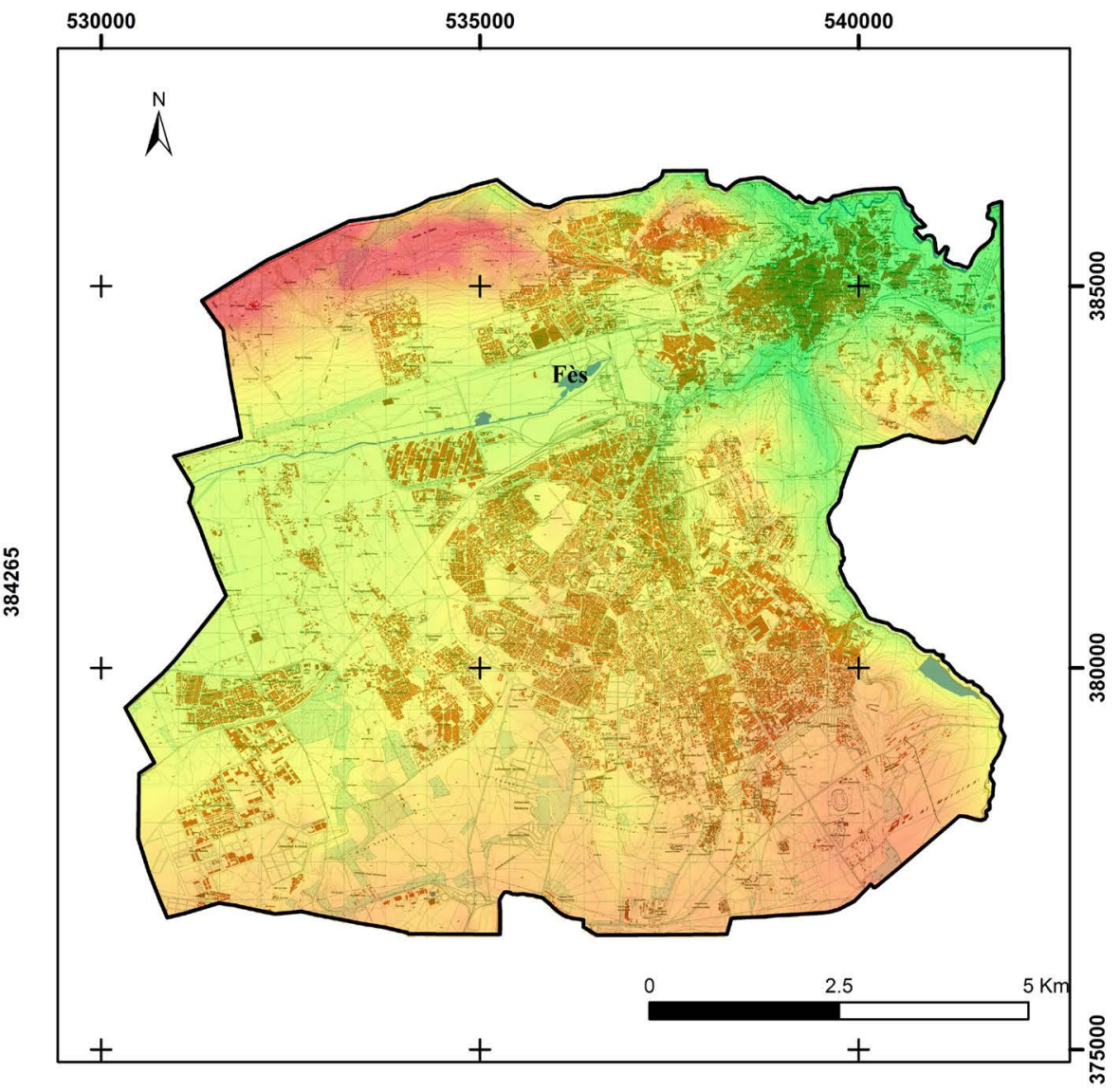

Figure 1. Location map of the city of Fez. 
which constitutes his greatest wealth mainly with arboriculture, cereals and legumes, etc. According to the 2014 census, the population of this city is about $1,112,072$ habitants [5].

\subsection{Climate Context}

The region of the city of Fez has several weather stations distributed well and distant from each other. The data from the Fez-HRD station are used to develop this study because of its proximity to the study area and the detail it offers over a long period of the region's climatologically history.

The observation of monthly (Figure 2) and annual (Figure 3) mean precipitation histograms established over a 34-year period, from 1980/1981 to 2013/2014, shows that the year is divided into two seasons. A dry season extends from June to September, which corresponds to the summer season; and a wet season which extends from October to May. The rainiest months of this season are the months from November to January.

The average annual rainfall shows a significant inter-annual irregularity with an irregular alternation of more or less wet periods and more or less dry periods. The driest periods record an average rainfall around $200 \mathrm{~mm}$ while the wettest

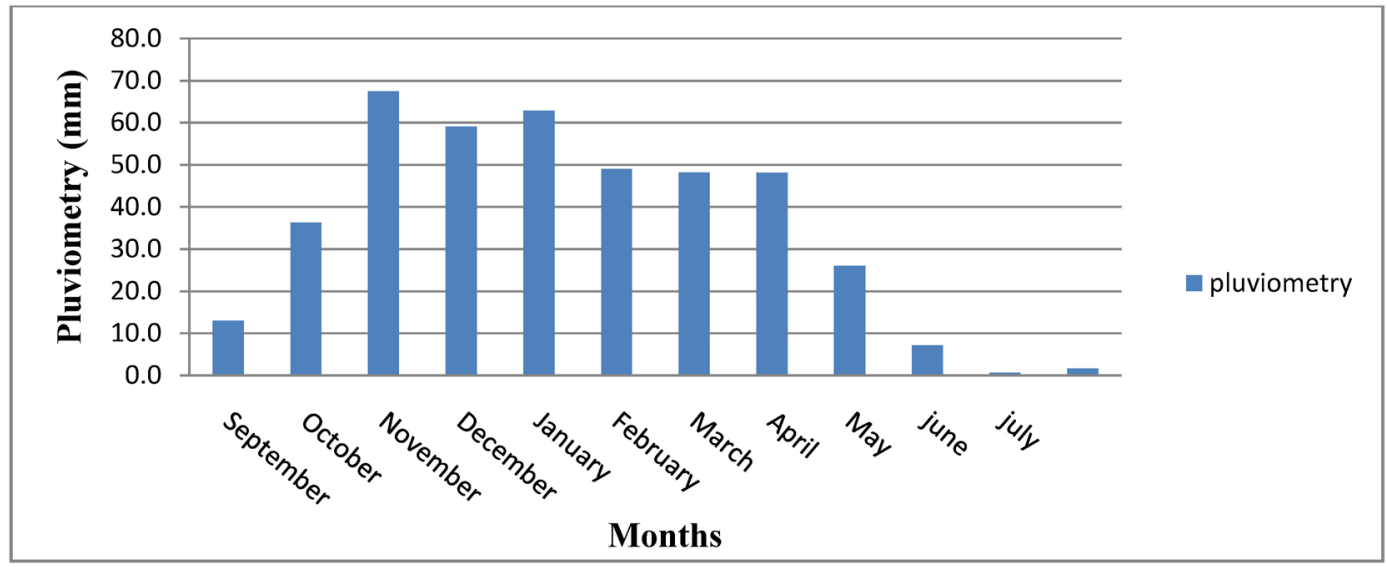

Figure 2. Average monthly rainfall [6].

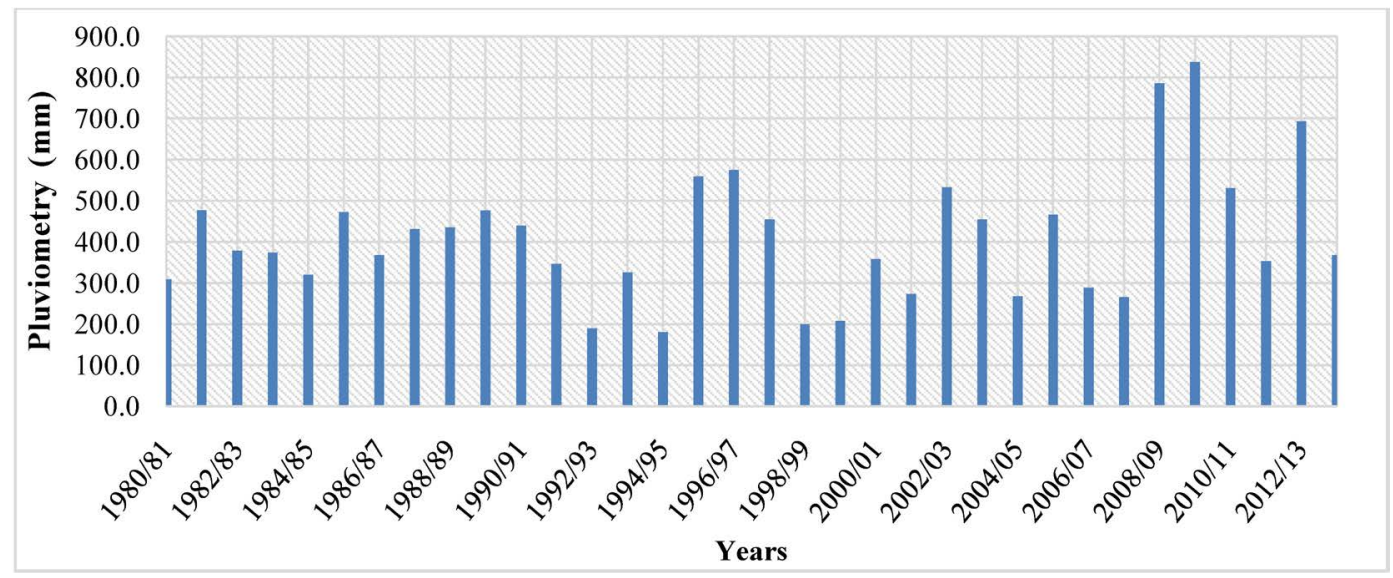

Figure 3. Average annual rainfall between 1980 and 2014 [6]. 
periods record an average rainfall around $800 \mathrm{~mm}$. Between these extreme periods, there are periods of average rainfall in the order of 400 to $500 \mathrm{~mm}$. These periods are the most frequent during the last three decades.

\subsection{Hydrological Context}

Figure 4 shows that the hydrology of the region of Fez is characterized by a hydrographic system centered on the Oued Fez which flows from west to east, from its sources in Ras El Ma to the Sebou, crossing the old medina of Fez. Oued Fez has several tributaries along its route that are nourished by groundwater resurgences such as Oued El Mahraz, Oued El Miyet and Oued Boufekrane, and others that drain mainly runoff water: Oued El Mellah, Oued Smen, Oued Ain chkef [7]. It is bounded to the north by the ridge line corresponding to the pre-Rife wrinkles, to the west by the Oued Nja basin, to the east by the Sebou basin and to the south by the cliffs of the Middle Atlasic Causse of Immouzer [8].

\subsection{Hydrological Context}

The Saïss basin has two important water tables: a deep-water table and a superficial water table. The deep-water table, which constitutes the extension of the free

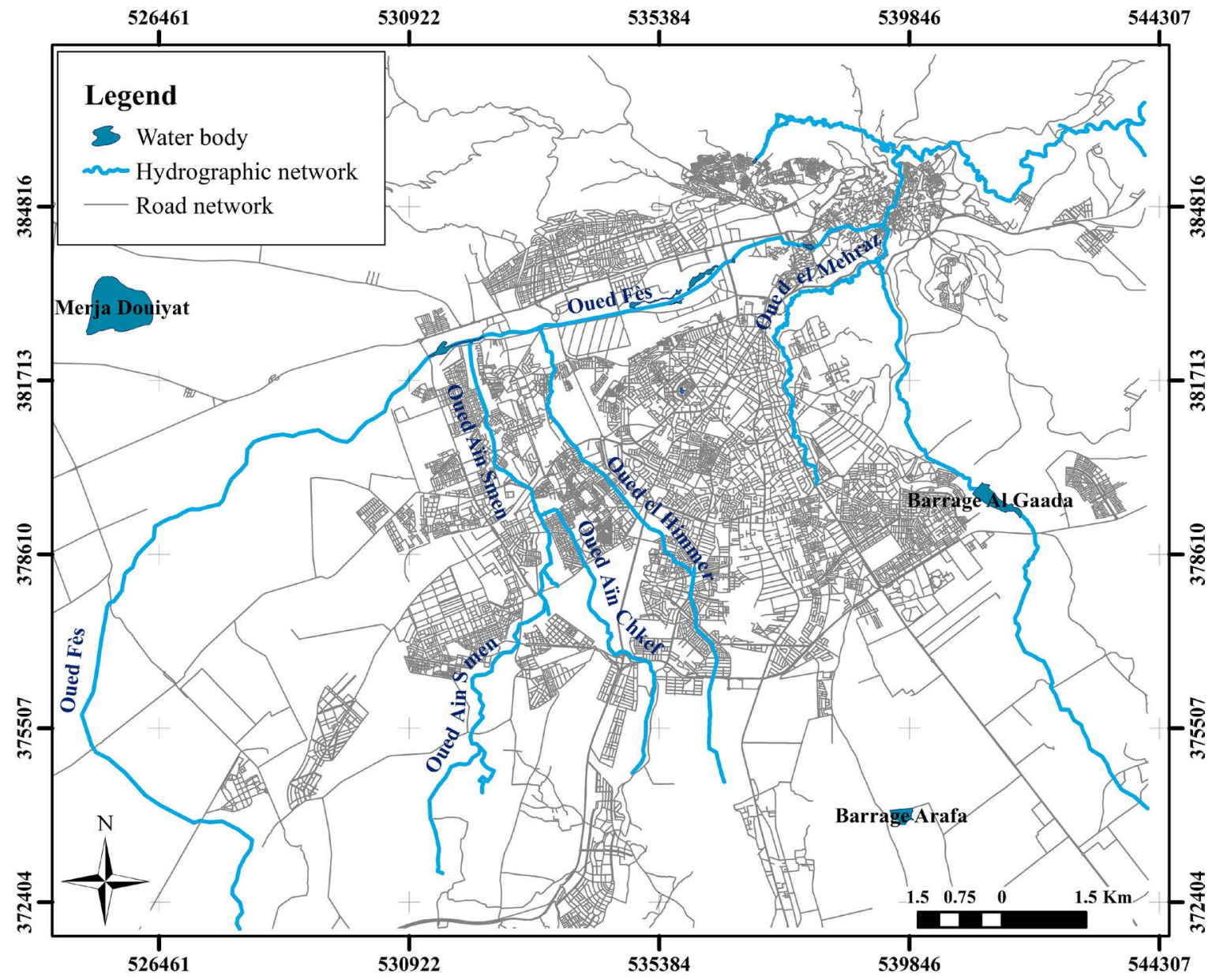

Figure 4. Map of the hydrographic network of the city of Fez. 
table of the Middle North Atlasian Causse towards the North, is contained in the dolomitic and calcareous carbonate formations of the Lias.

This water table, which becomes captive in the Saïs, has Triassic clays and Paleozoic shales as its floor. It is buried under the neogenous marine and plioquaternary continental formations. Its depth in the northern part of the Fez Saiss basin reaches more than $1000 \mathrm{~m}$. This water table, whose waters have been warmed by geothermal gradient, resurgent, through faults, giving mineral thermal sources, which the most important are respectively the source of Sidi Hrazem and that of Moulay Yacoub.

The surface water table is located in the yellowish marine sandstones of the Upper Miocene, Middle Pliocene and fluvio-lacustrine and fluvial formations of the Plio-quaternary. This water table, whose base is the sandy marls of the Upper Miocene, resurgent in the form of sources of higher flows, such as the Ras El Ma and Ain Chkef sources. These sources ensure the perenniality of the flow of the Oueds which constitute the hydrographic network of Oued Fez [9].

\section{Materials and Methods}

This work is based on the study of the integration of the systems of rainwater reuse, and purified, in order to valorize them in the watering of the green spaces of the city, and the irrigation of the agricultural spaces surrounding the water treatment plant.

\subsection{State of the City's Green Spaces}

Since its foundation, the city of Fez had several green spaces; however following massive urbanization and the anarchic growth of several neighborhoods, they became rare. Similarly, most of the land destined for green spaces in the area of some public housing projects is still abandoned.

It would be very important to know the current state of the green spaces of Fez and the watering systems adopted, before addressing the lively subject, this could only be done by doing the following steps:

- Delimiting the green spaces of the city;

- Determining the total area of green spaces in the city and calculating the ratio of green spaces per inhabitant;

- Conceive an idea on the watering systems adopted.

These steps will be realized by relying on the database of green spaces provided by the Urban Agency of the city of Fez.

\subsection{Watering Needs}

To determine the net water needs $(B n)$, the method used is based on the reference evapotranspiration $\left(E T_{0}\right)$, the nature of the soil and the existing types of plant [6].

$$
B n=\left(\left(E T_{0} \times K c \times K r\right)\right) / E a
$$

With 
- $B n$ : net watering needs;

- $E T_{0}$ : reference evapotranspiration in $\mathrm{mm} / \mathrm{d}$;

- Kc. cultural coefficient;

- Kr. rationing coefficient per stage;

- Ea: coefficient of application of water to the parcel.

Table 1 represents variation of the value of the reference evapotranspiration (ET0) during the months; it reaches its maximum value in July with $199.95 \mathrm{~mm}$.

\subsection{Impluvium Surface}

The purpose of this step is to calculate the total area necessary for rainwater collection. The method used is based essentially on the maximum volume required for watering and rainfall in the zone [10].

$$
S_{\max }=\frac{V_{\max }}{P \times K T \times K F}
$$

With

- $V_{\max }$ : Maximum volume of rainwater recoverable annually in liters;

- $P$. Annual rainfall in $\mathrm{mm}$;

- $S_{\max }$ : Impluvium surface in $\mathrm{m}^{2}$;

- KT: restitution coefficient and KF: coefficient of the filtration system.

The restitution coefficient $(K T)$ varies according to the nature of the surface of the impluvium. Table 2 shows the different $K T$ for the different surface types.

The coefficient $(K F)$ represents the hydraulic efficiency coefficient of the filtration system; it is around 0.9 for new and/or well-maintained systems.

\subsection{Purified Water}

The city of Fez is equipped with a wastewater treatment plant adopting an activated sludge treatment technique, which allows the reduction of chemical and organic pollution making wastewater a potential resource. Hence the reuse of this water is necessary in the irrigation of peri-urban agricultural fields.

The aim of this step is to focus on the quality of treated wastewater and to

Table 1. Reference evapotranspiration $\left(E T_{0}\right)$ monthly [6].

\begin{tabular}{ccccccccccccc}
\hline Designation & Sept. & Oct. & Nov. & Dec. & Jan. & Feb. & Mar. & Apr. & May. & June. & July. & Aug. \\
\hline$E T_{0}$ (mm/Day) & 4.33 & 2.9 & 1.87 & 1.29 & 1.23 & 1.54 & 2.03 & 2.63 & 3.48 & 4.97 & 6.45 & 6.03 \\
Day per month & 30 & 31 & 30 & 31 & 31 & 28 & 31 & 30 & 31 & 30 & 31 & 31 \\
$E T_{0}$ (mm/Month) & 129.9 & 89.9 & 56.1 & 39.99 & 38.13 & 43.12 & 62.93 & 78.9 & 107.88 & 149.1 & 199.95 & 186.93 \\
\hline
\end{tabular}

Table 2. Coefficient of restitution according to surface types [10].

\begin{tabular}{cc}
\hline Type of coverage & Coefficient $(K T)$ \\
\hline Hard material surface on slope & 0.9 \\
Sloping undulating surface & 0.8 \\
Terrace roof & 0.6 \\
\hline
\end{tabular}


quantify the flow that the treatment plant can provide, the method is based on the purification plant's efficiency and the comparison with Moroccan standards related to the discharge and reuse of treated water (Table 3 and Table 4).

\subsection{Peri-Urban Agriculture}

The peri-urban agriculture in the city of Fez has always been a significant source of supply of agricultural products, mainly vegetables. These products are ready for direct consumption, they are less requiring in terms of packaging, storage and transport because of the proximity of the city.

The purpose of this step is to determine the irrigation water needs of the agricultural fields adjacent to the treatment plant (Figure 5) according to the following steps:

Table 3. Limit values for wastewater discharge from urban agglomerations [11].

\begin{tabular}{cc}
\hline Parameters & Specific limit values for domestic discharges \\
\hline BOD5 mg O2/l & 120 \\
COD mg O2/l & 250 \\
TSS mg/l & 150 \\
\hline
\end{tabular}

Table 4. Limit values for toxic elements for water destined for irrigation [11].

\begin{tabular}{cc}
\hline Parameters & Limit values specific to use in irrigation \\
\hline $\mathrm{Al}(\mathrm{mg} / \mathrm{l})$ & 5 \\
$\mathrm{Cd}(\mathrm{mg} / \mathrm{l})$ & 0.01 \\
$\mathrm{Cr}(\mathrm{mg} / \mathrm{l})$ & 0.1 \\
$\mathrm{Cu}(\mathrm{mg} / \mathrm{l})$ & 0.2 \\
$\mathrm{~Pb}(\mu \mathrm{g} / \mathrm{l})$ & 5
\end{tabular}

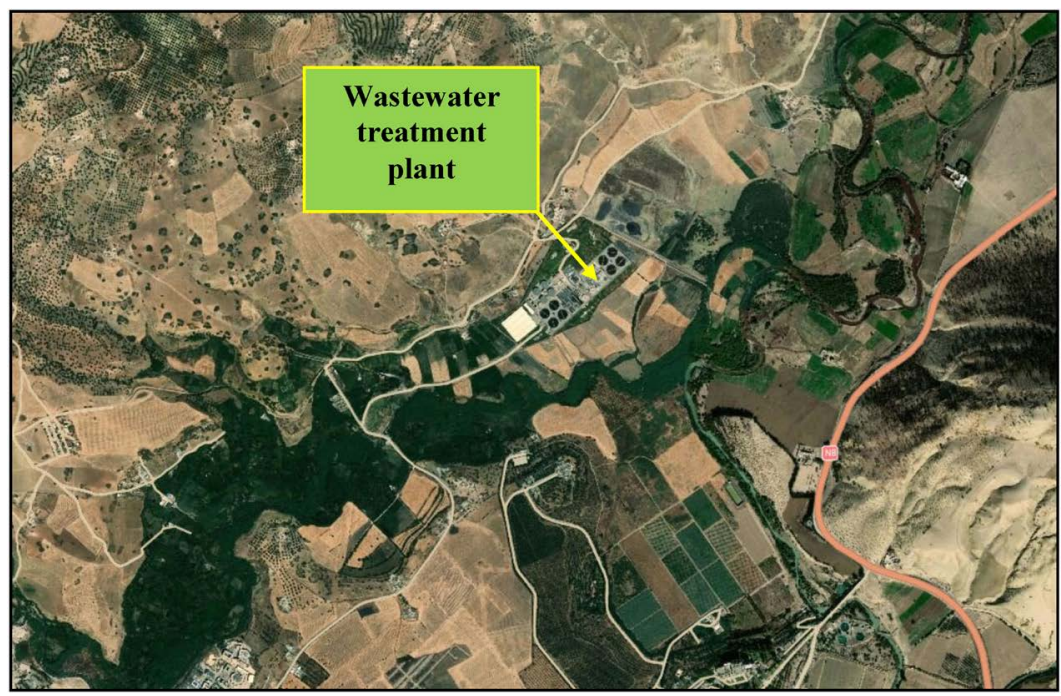

Figure 5. Location of agricultural fields in relation to the wastewater treatment plant (Google Map view). 
- Delimitation of irrigated areas;

- Determination of water needs;

- Comparison of irrigation water needs/purified water flows.

\section{Results and Discussion}

\subsection{State of the Green Spaces}

Based on the data available at the Urban Agency of Fez, the green spaces were classified by district and according to the watering systems adopted and the types of space (public garden, park, planted crossroads ...).

It is clear that the old districts such as Agdal, Merinides, and Medina include a large area of green space with respectively $31.45 \%, 27.12 \%, 25.13 \%$ of the total green spaces of the city (Table 5).

Nevertheless the ratio (Gs/inhab) which describes the ratio in $\mathrm{m}^{2}$ per inhabitant of green areas still very far from the average recommended by the WHO which is between 10 and $14 \mathrm{~m}^{2} /$ inhab. The Zouagha district records the lowest ratio of the city with $0.11 \mathrm{~m}^{2}$ of green spaces per inhabitant.

According to the results presented in Table 6, it is essential to put in place a strategy to upgrade green spaces and create new ones, especially for new housing developments.

The results obtained from the analysis of the city's green spaces database (Figure 6) show that:

- $41 \%$ of green spaces are neglected without watering, i.e. $250,496 \mathrm{~m}^{2}$;

- Only $12 \%$ of the green spaces are watered by Oueds;

- $12 \%$ of the spaces are watered by tank trucks, i.e. $71,517 \mathrm{~m}^{2}$. This sprinkler system is subject to machine availability, thus preventing the normal operation of the sprinkler system;

- $31 \%$ of the green spaces are watered by sprinklers;

- $4 \%$ of green spaces are watered and maintained by neighborhood associations or residents.

\subsection{Watering Requirements}

The watering water need was calculated essentially on the basis of the total unwatered area " $250,496 \mathrm{~m}^{2}$ ", i.e. $41 \%$ of the total area of the city's green spaces. The results are shown in Table 7.

Table 5. Area of green spaces by district and index Gs/inhab.

\begin{tabular}{ccccccc}
\hline District & Population $(2014)$ & S public gardens $\left(\mathrm{m}^{2}\right)$ & $\mathrm{S}$ public places $\left(\mathrm{m}^{2}\right)$ & Others $\left(\mathrm{m}^{2}\right)$ & Total $\left(\mathrm{m}^{2}\right)$ & Gs $/$ inhab. $\mathrm{m}^{2} /$ inhab. \\
\hline Agdal & 142,407 & $139,606.50$ & 23,211 & 28,050 & $190,867.5$ & 1.340 \\
Merinides & 209,494 & $158,443.50$ & 2126 & 4026 & $164,595.5$ & $\mathbf{0 . 7 8 5}$ \\
Saïss & 207,345 & $58,222.74$ & 11,390 & 250 & $69,862.74$ & $\mathbf{0 . 3 3 6}$ \\
Zouagha & 260,663 & 26,221 & 2798 & - & 29,019 & $\mathbf{0 . 1 1 1}$ \\
$\begin{array}{l}\text { Medina- } \\
\text { Mechouar }\end{array}$ & 292,163 & 76,824 & 75,688 & - & 152,512 & $\mathbf{0 . 5 2 2}$
\end{tabular}


Table 6. Percentage of watering systems by district [12].

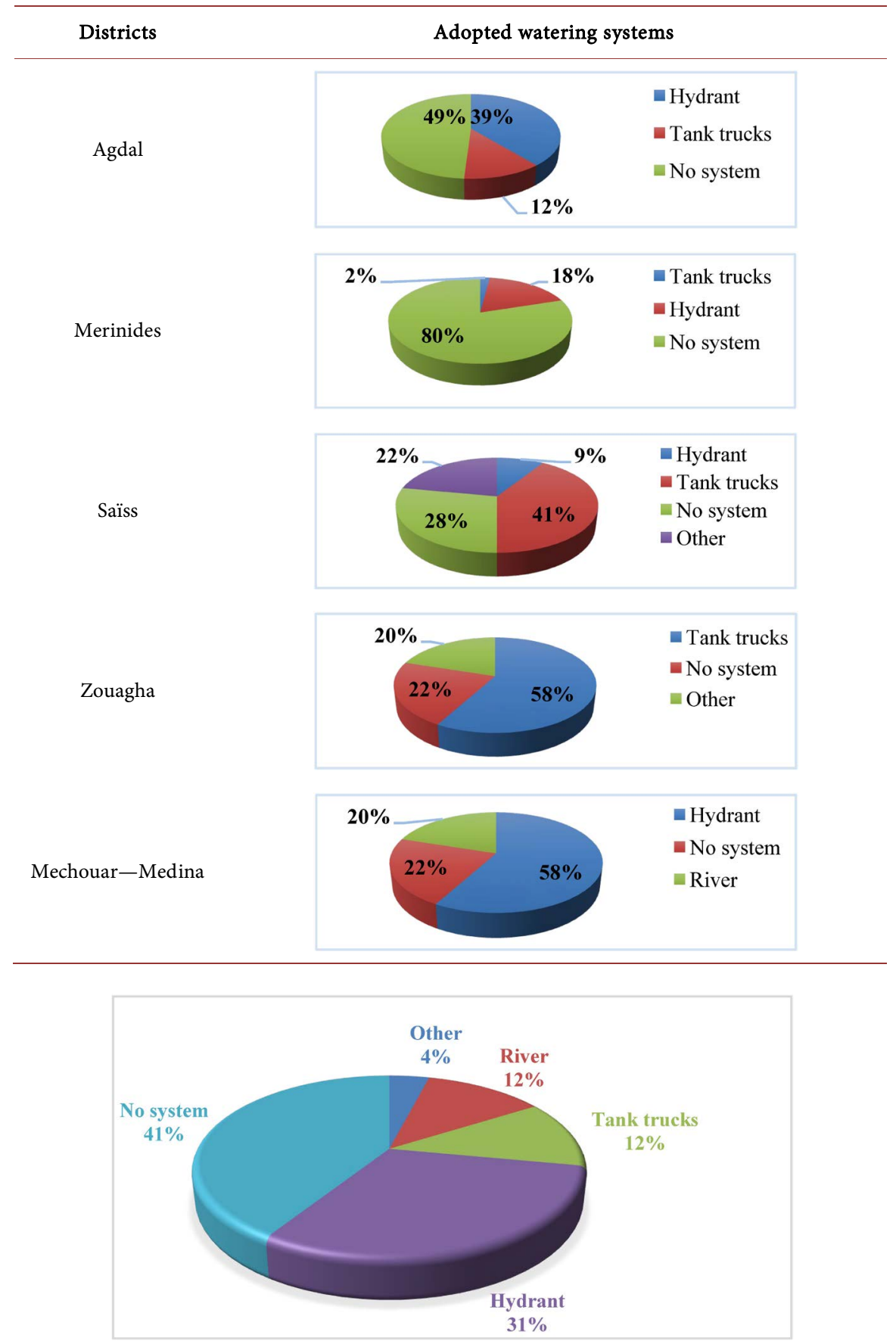

Figure 6. Percentages of watered and un-watered green spaces.

Table 7. Monthly watering needs for green spaces.

\begin{tabular}{ccccccc}
\hline Month & Sept. & Oct. & Nov. & Dec. & Jan. & Feb. \\
\hline Gross need (m ${ }^{3} /$ month) & $12,629.17$ & 8740.28 & 5454.17 & 3887.92 & 3707.08 & 4192.22 \\
\hline Month & Mar. & Apr. & May. & June. & July. & Aug. \\
\hline Gross need (m 3 /month) & 6118.19 & 7670.83 & $10,488.33$ & $14,495.83$ & $19,439.58$ & $18,173.75$
\end{tabular}


After the superposition of the monthly watering needs and the rainfall (Figure 7), it was proved that the latter can satisfy the watering needs from October until April, knowing that the transfer of the rainfall from $\mathrm{mm}$ to $\mathrm{m}^{3}$ was done through the formula: $1 \mathrm{~mm}=10 \mathrm{~m}^{3} / \mathrm{ha}\left(10 \mathrm{~m}^{3}\right.$ divided by $10,000 \mathrm{~m}^{2}$ equal to $0.001 \mathrm{~m}$ which is $1 \mathrm{~mm}$ ).

The period from May to September has a low rainfall and a high demand for watering water, which requires the integration of watering during this period. The calculation of the required watering volumes is based on the difference in water requirements and rainfall (Table 8 ).

The red cells in Table 8 show the volumes of water needed for watering when the needs exceed the volume of precipitation. The total annual volume missing to meet watering needs is $63,089.17 \mathrm{~m}^{3}$.

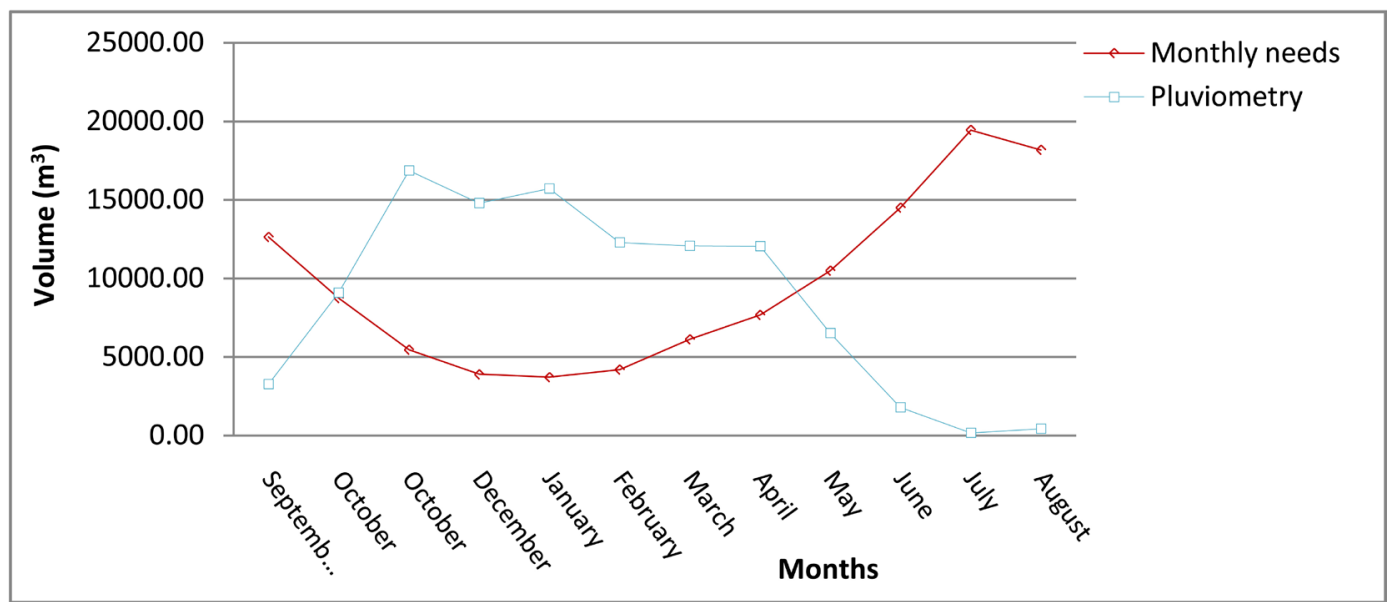

Figure 7. Monthly watering and rainfall requirements.

Table 8. Monthly watering volumes requested.

\begin{tabular}{cccc}
\hline & Precipitation Volume $\left(\mathrm{m}^{3}\right)$ & Needs $\left(\mathrm{m}^{3}\right)$ & $\mathrm{V}-\mathrm{N}$ \\
\hline September & 3262.50 & $12,629.17$ & 9366.67 \\
October & 9085.00 & 8740.28 & 344.72 \\
November & $16,855.00$ & 5454.17 & $11,400.83$ \\
December & $14,785.00$ & 3887.92 & $10,897.08$ \\
January & $15,720.00$ & 3707.08 & $12,012.92$ \\
February & $12,272.50$ & 4192.22 & 8080.28 \\
March & $12,050.00$ & 6118.19 & 5931.81 \\
April & $12,030.00$ & 7670.83 & 4359.17 \\
May & 6515.00 & $10,488.33$ & $\mathbf{3 9 7 3 . 3 3}$ \\
June & 1787.50 & $14,495.83$ & $\mathbf{1 2 , 7 0 8 . 3 3}$ \\
July & 160.00 & $19,439.58$ & $\mathbf{1 9 , 2 7 9 . 5 8}$ \\
August & 412.50 & $18,173.75$ & $\mathbf{1 7 , 7 6 1 . 2 5}$ \\
\hline
\end{tabular}




\subsection{Impluvium Surface}

Storing rainwater in order to reuse it for watering green spaces is mainly done during the rainy months when rainfall exceeds watering needs.

Based on the total annual volume to be collected for watering, we determine the area of the impluvium that can provide this volume.

It comes out that to adopt rainwater recuperation systems for watering green spaces; the city of Fez must devote $184,470.76 \mathrm{~m}^{2}$ of these impermeable spaces to rainwater recuperation (Table 9 ).

So, for watering $250,464 \mathrm{~m}^{2}$ of the city's green spaces (Gs), we need to collect rainwater with an impermeable surface of $184,470.76 \mathrm{~m}^{2}$.

The ratio (I/Gs) between the surface of the impluvium and the surface to be watered is 0.74 , therefore for each $\mathrm{m}^{2}$ to be watered; the surface of the impluvium must be equal to $0.74 \mathrm{~m}^{2}$ (Table 10 ).

The analysis of these data shows that it is possible to ensure the volumes of water necessary for watering the green spaces of each district by using the surface of the impluvium which corresponds to it (Table 10). The largest surface of impluvium is $96,760.22 \mathrm{~m}^{2}$ corresponds to the Merinides district.

\subsection{Purified Water}

The parameters fixed to evaluate the quality of treated water are: Aluminum, Cadmium, Chromium, Copper, Lead, BOD5 (biological oxygen demand), COD (chemical oxygen demand), TSS (suspended matter) (Table 11).

The comparison of the results of analysis of chemical elements and heavy metals with the Moroccan irrigation water standards fixed by the Ministry of Energy, Mines, Water and Environment in charge of water (2015) shows that they are below the thresholds fixed (Table 12).

The treated water is chemically satisfactory with a concentration of heavy metals well below that of the standards in force.

The comparison of the organic charge of the purified water with the standards shows that the concentration of the purified water is significantly lower than the

Table 9. Total surface of the impluvium of the city of Fez.

\begin{tabular}{ccccc}
\hline Annual volume $\left(\mathrm{m}^{3}\right)$ & Annual rainfall $(\mathrm{mm})$ & $\mathrm{KT}$ & $\mathrm{KF}$ & Impluvium area $\left(\mathrm{m}^{2}\right)$ \\
\hline 63,089 & 475 & 0.8 & 0.9 & $\mathbf{1 8 4 , 4 7 0 . 7 6}$ \\
\hline
\end{tabular}

Table 10. Impluvium area for each district of the city of Fez.

\begin{tabular}{cccc}
\hline District & Area to be watered & Ratio I/Gs & Impluvium surface $\left(\mathrm{m}^{2}\right)$ \\
\hline Agdal & $92,783.5$ & $68,326.44$ \\
Merinides & 131,395 & 0.73641 & $96,760.22$ \\
Saïs & $19,643.74$ & $14,465.79$ \\
Zouagha & 6480 & 4771.92 \\
Medina & 194 & 142.86 \\
\hline
\end{tabular}


standards in effect (Figure 8).

Taking in consideration the two previous comparisons of the chemical and organic elements of the purified water and the Moroccan standards in effect (Table 12 and Figure 8); it appears that the reuse of the purified water from the Fez city station in the irrigation of peri-urban fields is possible on condition of bacteriological analyses.

\subsection{Peri-Urban Agriculture}

The total cultivable area of the agricultural fields adjacent to the wastewater treatment plant amounts to more than 84 ha. The crops grown are generally cereals, vegetables and olives.

Table 11. Results of treated water analysis.

\begin{tabular}{cc}
\hline Parameters & Measured value \\
\hline $\mathrm{Al}(\mathrm{mg} / \mathrm{l})$ & $<0.01$ \\
$\mathrm{Cd}(\mathrm{mg} / \mathrm{l})$ & $<0.01$ \\
$\mathrm{Cr}(\mathrm{mg} / \mathrm{l})$ & $<0.01$ \\
$\mathrm{Cu}(\mathrm{mg} / \mathrm{l})$ & 0.08 \\
$\mathrm{~Pb}(\mu \mathrm{g} / \mathrm{l})$ & 0.05 \\
$\mathrm{BOD} 5(\mathrm{mg} / \mathrm{l})$ & 30 \\
$\mathrm{COD}(\mathrm{mg} / \mathrm{l})$ & 125 \\
$\mathrm{TSS}(\mathrm{mg} / \mathrm{l})$ & 35 \\
\hline
\end{tabular}

Table 12. Comparison of analytical results with Moroccan standard.

\begin{tabular}{cccc}
\hline Parameters & Measured value & Standard & Observation \\
\hline $\mathrm{Al}(\mathrm{mg} / \mathrm{l})$ & $<0.01$ & 5 & Satisfactory quality \\
$\mathrm{Cd}(\mathrm{mg} / \mathrm{l})$ & $<0.01$ & 0.01 & Satisfactory quality \\
$\mathrm{Cr}(\mathrm{mg} / \mathrm{l})$ & $<0.01$ & 0.01 & Satisfactory quality \\
$\mathrm{Cu}(\mathrm{mg} / \mathrm{l})$ & 0.08 & 0.2 & Satisfactory quality \\
$\mathrm{Pb}(\mu \mathrm{g} / \mathrm{l})$ & 0.05 & 5 & Satisfactory quality \\
\hline
\end{tabular}

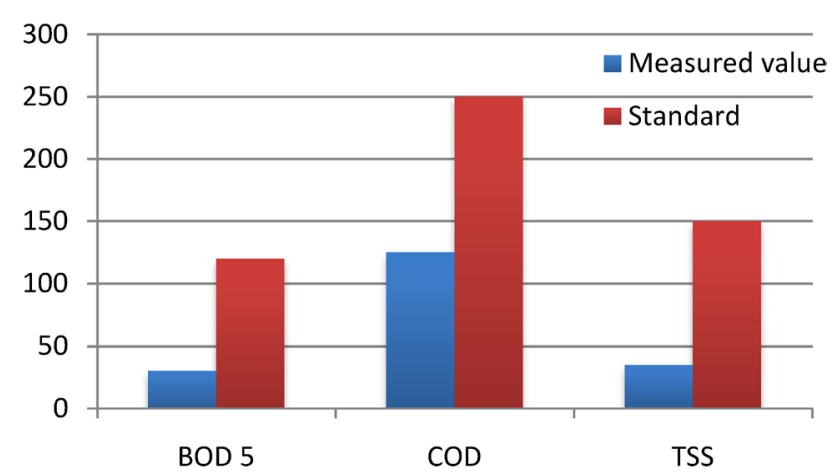

Figure 8. Comparison of BOD5, COD, and TSS values of treated water with the Moroccan standard. 
The monthly irrigation water needs of these fields are calculated taking into account the reference evapotranspiration $\left(E T_{0}\right)$, the total field area and the crops grown (Table 13).

According to the above curve, there are two periods: the first from October to April, when rainfall can satisfy irrigation water needs, and the second from May to September, when irrigation is necessary because water demand exceeds the recorded rainfall (Figure 9 ).

The irrigation of agricultural fields will take place during the period from May to September, as it is the period with the lowest rainfall and the highest demand.

The calculation of the requested irrigation water volumes is effected by the difference between the water requirements and the rainfall. The table below shows the volumes of water to be provided from agricultural fields during the less rainy months.

The results of the calculations (Table 14) show that the period from May to September has a maximum requirement that precipitation alone cannot satisfy and the total annual volume missing for satisfactory irrigation of the fields amounts to $315,278.39 \mathrm{~m}^{3}$.

The total annual volume missing from the irrigation of the surrounding agricultural fields at the treatment plant can be largely satisfied by the fact that the latter discharges a treated water flow fluctuating between 0.48 and $1.5 \mathrm{~m}^{3} / \mathrm{s}$, and if just the minimum flow is taken in consideration, the irrigation water needs can be largely satisfied.

Table 13. Monthly irrigation water needs of agricultural fields in the Fez region.

\begin{tabular}{ccccccc}
\hline Month & Sept. & Oct. & Nov. & Dec. & Jan. & Feb. \\
\hline $\begin{array}{c}\text { Gross need } \\
\left(\mathrm{m}^{3} / \text { month) }\right.\end{array}$ & $42,600.71$ & $29,482.71$ & $18,398.00$ & $13,114.72$ & $12,504.73$ & $14,141.20$ \\
\hline Month & March. & Apr. & May. & June. & July. & Aug. \\
\hline $\begin{array}{c}\text { Gross need } \\
\left(\mathrm{m}^{3} / \text { month }\right)\end{array}$ & $20,637.89$ & $36,225.36$ & $49,530.94$ & $73,346.0$ & $104,917.7$ & $98,085.91$ \\
\hline
\end{tabular}

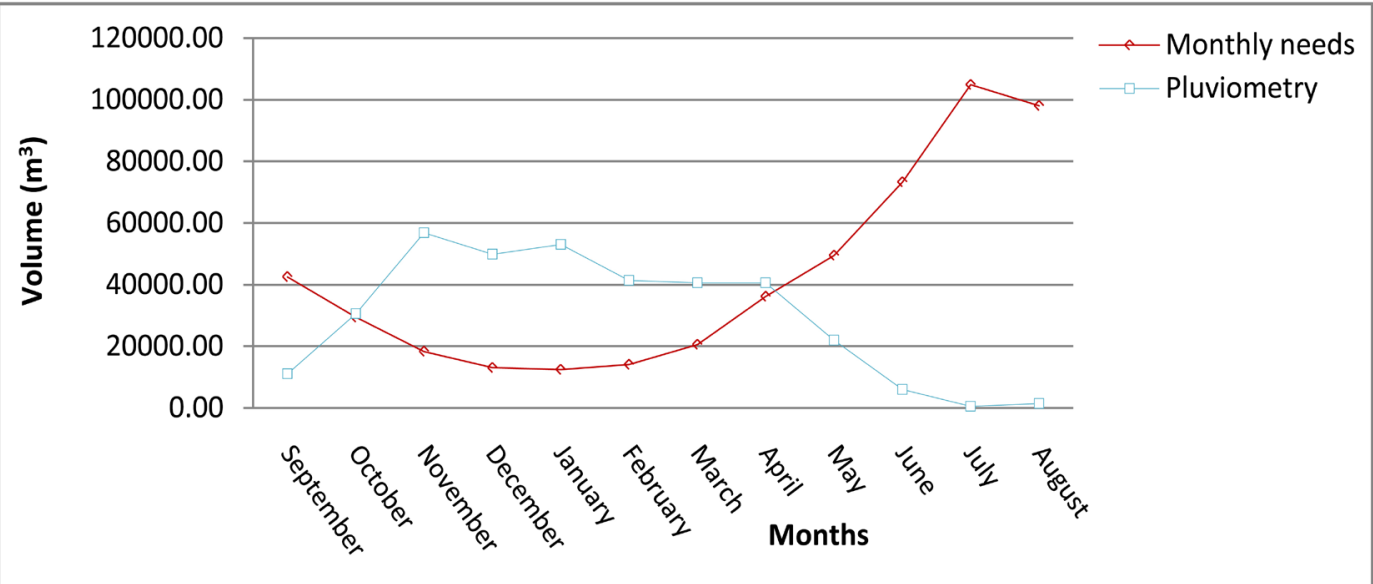

Figure 9. Irrigation water needs and monthly rainfall. 
Table 14. Requested monthly irrigation water volumes.

\begin{tabular}{cccc}
\hline & Precipitation volume $\left(\mathrm{m}^{3}\right)$ & Needs $\left(\mathrm{m}^{3}\right)$ & V - N \\
\hline September & $11,005.065$ & $42,600.71$ & $\mathbf{3 1 , 5 9 5 . 6 4}$ \\
October & $30,645.522$ & $29,482.71$ & 1162.82 \\
November & $56,855.286$ & $18,398.00$ & $38,457.29$ \\
December & $49,872.762$ & $13,114.72$ & $36,758.04$ \\
January & $53,026.704$ & $12,504.73$ & $40,521.97$ \\
February & $41,397.597$ & $14,141.20$ & $27,256.39$ \\
March & $40,647.06$ & $20,637.89$ & $20,009.17$ \\
April & $40,579.596$ & $36,225.36$ & 4354.24 \\
May & $21,976.398$ & $49,530.94$ & $\mathbf{2 7 , 5 5 4 . 5 5}$ \\
June & 6029.595 & $73,346.02$ & $\mathbf{6 7 , 3 1 6 . 4 2}$ \\
July & 539.712 & $104,917.76$ & $\mathbf{1 0 4 , 3 7 8 . 0 5}$ \\
August & 1391.445 & $85,825.17$ & $\mathbf{8 4 , 4 3 3 . 7 3}$ \\
\hline
\end{tabular}

\section{Conclusion}

The study of the possibility for reusing rain and purified water in the city of Fez, has shown that it's feasible to reuse rainwater in the watering of green spaces for the city. Moreover, the quality and the quantity of treated wastewater issued from the wastewater treatment plant of Fez can largely satisfy the water needs required by agricultural spaces in the nearby. Such an approach is highly recommended because it offers economic and environmental advantages through the preservation of natural resources and the valorization of treated water. However, rainwater storage is complicated due to the fact that it requires more space for installation of retention basins, something that is difficult to achieve in a country that struggles financially. The integration of treated and rainwater reuse systems in the city of Fez can only be achieved through the adoption of a participatory approach bringing together all stakeholders in the water and environment sector in the city.

\section{Conflicts of Interest}

The authors declare no conflicts of interest regarding the publication of this paper.

\section{References}

[1] International Water Management Institute (IWMI) (2010) Wastewater Irrigation and Health: Assessing and Mitigating Risk in Low-Income Countries. Earthscan, London.

[2] WHO (2006) Guidelines for the Safe Use of Wastewater, Excreta and Grey Water. Vol. 2, Wastewater Use in Agriculture, World Health Organization, France.

[3] Boutfirass, M. (2011) Techniques de récolte des eaux pluviales: leur utilisation et leur potentiel au Maroc, Agence de bassin hydraulique de Souss Massa Darâa Aga- 
dir.

[4] Epaulard, E. (1981) Description de l'Afrique, Leon l'africain Maisonneuve, Paris, Vol. 1, 181.

[5] Haut-commissariat au Plan (2014) Recensement Général de la Population et de l'Habitat (RGPH).

[6] ABHS (2015) Données de pluviométrie de la station DRH-Fès (X: 535400; Y: 384800).

[7] Elouali Lalami, A., Merzouki, M., Elhilali, O., Maniar, S. and Ibnsouda Koraichi, S. (2011) Pollution des eaux de surface de la ville de Fès au Maroc: Typologie, origine et conséquences. Larhyss Journal, No. 9, 55-72.

[8] Reynard, E., Werren, G., Lasri, M., Obda, K. and Elkhalki, Y. (2011) Carte des phénomènes d'inondation des bassins de Fès et Béni Mellal. Mémoires de la Société vaudoise des sciences naturelles, 25, 71-81.

[9] Elmsaddaq, K. (2005) Synthèse hydrogéologique dans la plaine de Saïss: secteur Fès. Mémoire DESA. Université Sidi Mohamed ben Abdellah. Faculté des sciences.

[10] ABHS (2012) Etude du plan directeur de la collecte des eaux pluviales au niveau du bassin du Sebou, 30 .

[11] Ministère délégué auprès du Ministre de l'Energie, des Mines, de l'Eau et de l'Environnement, chargé de l'Eau (2015) Recueil des textes juridiques relatifs aux ressources en eau au Maroc, 325.

[12] Agence urbaine et sauvegarde Fès (AUSF) (2014) Rapport de diagnostic des espaces verts de la ville. 